November 2013

\title{
Counterinsurgency and Union Movement in El Salvador (1967-1968)
}

Lucrecia Molinari

CONICET-Genocide Studies Centre - National University of Tres de Febrero-Argentina

Follow this and additional works at: https://digitalcommons.usf.edu/gsp

\section{Recommended Citation}

Molinari, Lucrecia (2013) "Counterinsurgency and Union Movement in El Salvador (1967-1968)," Genocide Studies and Prevention: An International Journal: Vol. 8: Iss. 1: Article 7.

DOI: http://dx.doi.org/10.5038/1911-9933.8.1.5

Available at: https://digitalcommons.usf.edu/gsp/vol8/iss1/7

This Articles is brought to you for free and open access by the Open Access Journals at Digital Commons @ University of South Florida. It has been accepted for inclusion in Genocide Studies and Prevention: An International Journal by an authorized editor of Digital Commons @ University of South Florida. For more information, please contact digitalcommons@usf.edu. 


\title{
Counterinsurgency and Union Movement in El Salvador (1967-1968)
}

\author{
Lucrecia Molinari \\ CONICET-Genocide Studies Centre - National University of Tres de Febrero-Argentina
}

Summary: The present paper analyzes the wave of protest lead by urban workers and the teacher union in 1967 and 1968 in El Salvador, and the repressive strategies that the State implemented in response to those protests.

Keywords: El Salvador, counterinsurgency, unionism, social mobilisation

Date of peer-review approval: April 22, 2013

\section{Introduction}

The present paper analyzes urban worker and teacher union labor protests between 1967 and 1968 in El Salvador. It also describes the strategies that the State, the security forces, and the paramilitary organizations implemented in response to those protests. Numerous studies analyze the way in which security forces and paramilitary groups responded to the protests and popular movements, emphasizing the challenge that guerillas had posed to the state since the mid-1970s. This paper takes issue with this perspective because, although guerrillas first arose in 1970 and became recognized in 1972, it is possible to detect a counterinsurgency structure in El Salvador as early as 1963 and a change in its function in 1967. This paper highlights the use of this counterinsurgency structure from its origins in 1963 to the protest wave that occurred from 1967 to 1968 ; that is, several years before the emergence of the guerrilla organizations. In this sense, the paper emphasizes the idea that the status quo was threatened by said mobilization before guerillas decided to take up arms. This fact must be linked to the characteristics of the social and political ties between the unions and teacher organizations that led the protests.

\section{El Salvador: The "glorious" years}

In the early 1960s, the Salvadoran production system was modified significantly which produced grave social and political consequences. The international context was characterized by strong pressure towards industrialization and political liberalization. Within this context, the military that had seized power in El Salvador in 1948 implemented a break with the previous period (1932-1948), which was characterized by repressive and reactionary governments that defended the interests of the traditional oligarchy of the coffee industry. ${ }^{1}$ The military implemented economic and political modernization measures aligned with post-second world war ideas. Their government was characterized by a certain amount of political openness. However, they continued to repress El Salvador's citizens. Other changes were reflected in a new legal framework. The 1950 Political Constitution expanded and redefined the state's role, allowing it to strongly intervene in the national economy. These new measures empowered the state to promote industrialization and to allocate national resources towards infrastructure. ${ }^{2}$

However, the main consequences of this turn of events become evident in the 1960s. In this decade, before the war between Honduras and El Salvador (July 1969), the MCCA (Mercado Común Centroamericano or Central American Common Market) was working at its full potential. As a result of this commercial integration, industrial and agricultural production, as well as inter-regional commercial trade, increased rapidly. This was especially evident in more developed countries of Central America, such as El Salvador and Guatemala. ${ }^{3}$ This is why the period between the mid-1950s and mid-1970s is known in this region as the "20 Glorious Years." 4

Successful economic integration promoted by the military resulted in meaningful economic growth. The benefits of this growth impacted each social sector differently. Thus, these benefits were concentrated mostly in the wealthiest economic classes. They also allowed the middle and working classes to rise, but they did not generate any meaningful changes for the poorest groups. ${ }^{5}$ The most significant industrial development in El Salvador took place between 1962 and 1966. ${ }^{6}$ Though the number of industrial employees was low, they were important actors in the government's development plan. Therefore, it was fundamental to create policies for this 
sector. This period was also characterized by cultural modernization, an increases in public expenditure, growth of the Salvadoran state apparatus, political openness, and decreases in state repression. This promoted middle class growth (made up by teachers, professors, professionals, technicians, and students) and also facilitated the formation of unions, confederations, and associations in this sector. ${ }^{7}$

Coupled with these events, electoral reform in 1963 changed the political atmosphere. ${ }^{8}$ This reform redefined the single-party electoral system that had been active since 1932. Many opposition parties achieved legal status and won seats in the Legislative Assembly. ${ }^{9}$ This promoted a period of growth for the legal political opposition until it reached its height in $1968 .^{10}$ The 1960s, and particularly the presidency of Julio Rivera (1962-1967), advanced the enforcement and enactment of basic labor rights (such as the right to join a union and to constitute associations among public and urban workers). By contrast, the Labor Code, approved in 1963 , strongly limited protest actions. ${ }^{11}$

\section{The installment of a counterinsurgency structure in the countryside}

The rural area presented an entirely different situation than that in the cities. The rural workers did not enjoy any of the aforementioned benefits. Salaries remained low and unions were forbidden. In fact, it was in the rural area where, in 1963, the counterinsurgency infrastructure was installed. Despite the fact that it had been run and financially supported by the United States in its beginnings, the counterinsurgency infrastructure functioned in accordance with the local government goals. That is to say, it was oriented to form a social base for the pro-government party rather than to strictly follow counterinsurgency principals.

The installation of a counterinsurgency infrastructure was linked to a shift in US foreign policy towards Central America. ${ }^{12}$ Thus, there were marked increases in the assistance and training of Salvadoran police and security forces. In addition, national security issues were deepened, including the preparation of strategies for possible counterinsurgency warfare. According to counterinsurgency guidelines, strategies should include:

1. the development of a military intelligence system;

2. the training of Central American armed forces for counterinsurgency warfare; and

3. an upgrade of available weapons and equipment. ${ }^{13}$

North American consultants arrived in El Salvador with those goals. While interventions by the United States in matters of internal security were common, the emphasis on using and training local agents was new. They wanted to turn local agents into efficient and collaborative forces. By doing so, consultants from the US sought to reduce marine invasions, which were frequently implemented in other Central American countries. ${ }^{14}$

Soon after, the members of the National Guard, a militarized police organization, were included in this training. The National Guard had developed strong ties with local landlords, since its function was to control the rural population. These landlords commonly supplemented the guards' modest wages through alternative forms of payment. Moreover, a command from the landlord was enough for a guard to arrest a rural worker. ${ }^{15}$ In this way, the National Guard was a public organization that provided services for private interests.

The training provided by the US gave them technical resources and methods that resulted in their increasing importance in national politics. There was an additional prestige for those in the group: they had access to military positions without having led a military career ${ }^{16}$ They were extensively prepared and had their own study centers and training schools. They were also involved in tuition programs for Ranger trainings in Panama under United States Southern Command (SOUTHCOM) supervision. The benefits of this training program were such that "Their members had 24 months of persistent training along with civil studies so after completion they would receive a substantially higher salary than other organizations."17

A year after the United States security program started training the National Guard, the National Defense Organization (known by the Spanish initials ORDEN, which also means order) was founded. ${ }^{18}$ Although some of its members were National Guard recruits, civilians with no military experience formed ORDEN's largest group. The civilians were mostly compelled to join, and they did so because of promises of land, affordable credits, supplies, permanent jobs, and healthcare. This was the only way to escape poverty for many peasants and having the ORDEN credential would prevent them from being victims of the repressive security forces. ${ }^{19}$ ORDEN managed to form an impressive control network and it mobilized between 100,000 and 150,000 people in $1974 .^{20}$ 


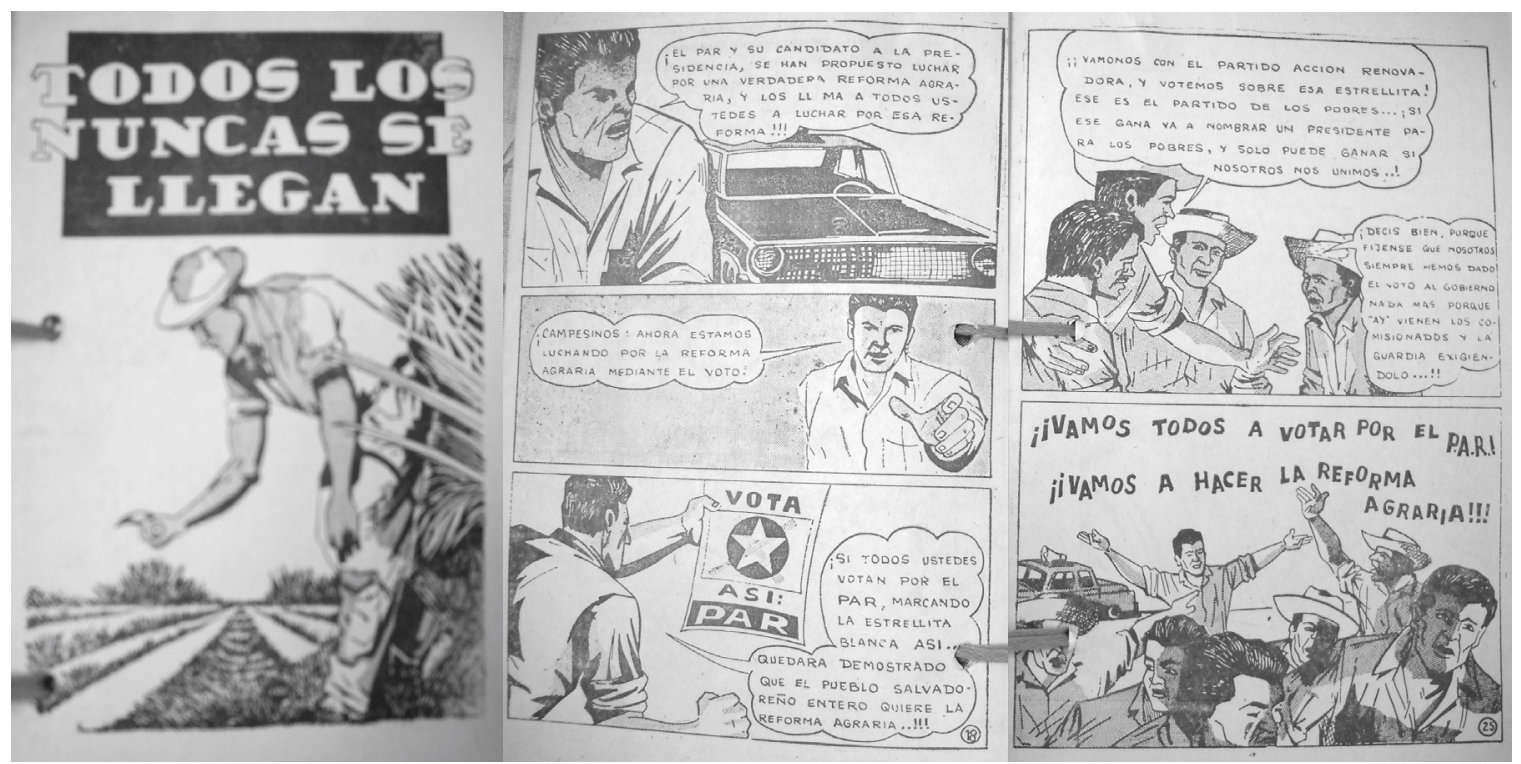

Fig. 1. Opposition party PAR's Flyer (1967) ${ }^{23}$. Source: Mexican ambassador's report. From the Mexican embassy in El Salvador. Acervo Histórico de la Secretaría de Relaciones Exteriores de México.

Although they were trained in counterinsurgency techniques, they served initially to fortify the social base of the pro-government party and the peasantry control, especially under Rivera's presidency (19621967). ${ }^{21}$ It is not a coincidence that these types of functions started amidst a context of emerging political openness and growth of opposition parties, along with the agitation and politicization of society.

This politicization responded to the possibilities opened by electoral reform in 1963 . The left-wing parties' actions were an example. Although they knew it was impossible to win, they took the opportunity in the pre-electoral context to develop broad political campaigns for "education and political awareness". 22 Some of these campaigns tried to appeal to the rural population as shown in Fig. 1.

ORDEN essentially served as a tool to prevent the agitation of rural workers. The politicization of the peasants was especially feared, since the inhumane working conditions in the countryside were the base of the Salvadoran oligarchy's wealth. Finally, ORDEN also secured the rural votes for the pro-government party, given that the peasants were the majority population.

\section{The cities: the beginnings of organizational infrastructure.}

As a result of the new labor laws and political openness, many worker organizations arose in the cities. Though some of these new worker organizations were independent and left-leaning, the pro-government organizations experienced the most growth. In order to increase effectiveness in their fight, the independent unions developed relationships with other similar worker organizations, creating networks. They thus established an organizational infrastructure that would later be able to sustain a determined critique of the political and economic order between 1967 and 1968.

\section{Pro-government Unions}

The military party supported a pro-government confederation -Confederación General de Sindicatos (CGS)- since 1950, favoring them over other organizations. The military party that took power in 1948 had decided to "take ideological and organic domain"24 of the union movement instead of eliminating it; the latter course of action had been the most utilized strategy in previous presidencies.

Improving the working conditions in the cities was a central objective of the new developmental state project (See Fig. 2), for evidence of the kind of dialogue between the president and pro-government unions even during time of strikes). However, it was not desirable that independent and autonomous unions be the ones to achieve this outcome. These unions were willing to push for concessions through the organization of massive demonstrations and by increasing the participation of popular classes. But these methods were considered too dangerous for the government. 
The dominance and heteronomy of the unions and popular classes' organizations were key parts in the authoritative, modernizing governments. They integrated the urban wage-earning sectors in a vertical and authoritative structure. They sought to construct the social base of the pro-government military party (called the Democratic Unification Revolutionary Party, PRUD, in the 1950s, and National Conciliation Party, PCN, in the 1960s). They also controlled, disciplined, and obstructed the independent organization of these sectors. To that end, the government promoted agreements with international organizations, such as the Inter-American Regional Organization of Workers and the American Federation of Labor-Congress of Industrial Organizations (AFL-CIO). They not only advised union matters in an anticommunist way, but also financed the pro-government unions. Thus, since its beginnings in 1958 the CGS constituted a very efficient channel to add workers to the pro-government party. ${ }^{25}$ This confederation continued to grow through the 1960s, reaching a critical point in 1967 when it controlled most of the unions.

\section{The independent unions}

Along with pro-government union support, there was also a constant persecution of left-wing unions and leaders. The independent strikers were discouraged. Belonging to a union that was not pro-government usually resulted in being laid off. This had severe implications considering the limited jobs available in the industry. The independent unions were centered in the Workers General Confederation of El Salvador (CGTS), which was founded in 1957. This organization went through a restructuring phase in 1965, when it changed its name to Unitary Federation of Unions of El Salvador (FUSS). FUSS was different from the pro-government unions because they were autonomous and did not receive any funding or orders from the State or any international organization, and they were not part of the official party. They also sought to overcome a corporate perspective. The wide range of their demands facilitated collaboration with other organizations, constituting a significant critique to the economic order. The autonomous nature of these organizations constituted a major challenge for the military, especially since they were trying to implement a development plan. In these kinds of projects, improving working conditions was desirable. However, the improvement was not to originate from autonomous actors, but rather in a disciplined manner and under the control of the State.

Additionally, the capacity to articulate different demands constituted a problem for the government as the military were trying to make a profound change in the relation between the State and the popular sectors. The most common answer to the demands of popular sectors, the plain repression, was replaced by a combination of repression, concessions, and co-optation of union leaders in the official party. Joining wide sectors, the independent organizations undermined the bases that the pro-government party funded

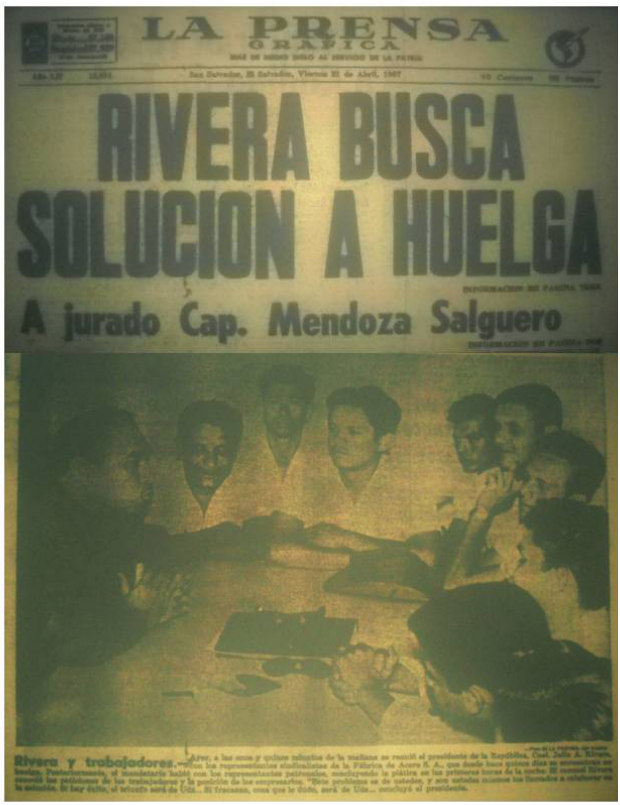

Fig. 2. La Prensa Gráfica Front Page ${ }^{26}$. Source: La Prensa Gráfica, 21/04/67. through an expensive client network, and that were held together through surveillance and regular control. Thus, the government was forced to repress the sectors it was trying to co-opt. ${ }^{27}$

The pro-government unions (CGS), in contrast, carried out a different strategy. They looked for small improvements in labor conditions that were fully in line with the government's authoritarian development program. Thus, they agreed with the economic path that the military government established, including the idea that a good relationship between capitalists and wage-earners was possible and desirable. In light of the growth of pro-government unions, the autonomous organizations had to protect their independence and reinforce their relationship with other unions and sectors. They are the ones who constituted the organizational infrastructure created during the political opening, which encouraged and supported the protest outbreaks since 1967.

\section{Protest outbreak (1967-1968)}

Towards the end of Julio Rivera's Presidential term (19621967) and the beginning of Fidel Sanchez Hernandez's time in office (1967-1972), there was a series of large and successful strikes that were unprecedented in Salvadoran history. 


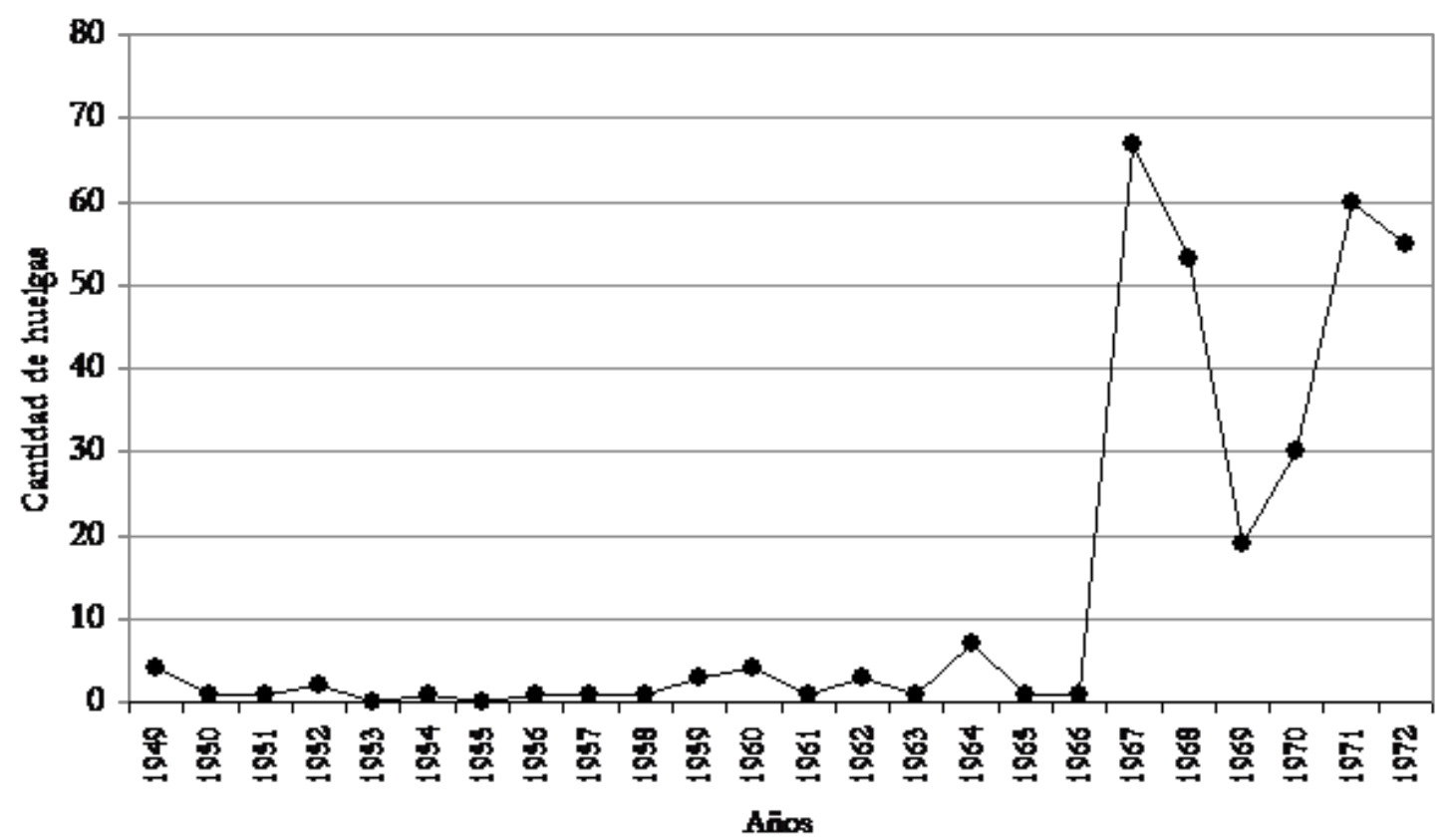

Fig. 3. Amount of Labor Strikes (1949-1972) ${ }^{28}$.

The workers were aware that after the politicization that characterized the electoral campaign period, presidential weakness would occur-especially between the elections and the start of the new presidency. Therefore, the workers realized that this was the right time to put pressure on the authorities. From 1967 to 1968 several successful strikes were carried out. The protests worth noting are:

1. the urban bus driver strike in January 1967 (organized by a union allied with FUSS, whose demands resulted in salary increases and an 8-hour work shift);

2. a strike in the largest textile factory in El Salvador, called IUSA, in February 1967 (organized by a CGS union that reached an agreement after an 8 day strike);

3. the strike action of garbage collection workers in February 1967 (supported by FUSS);

4. the protest organized by the workers of Acero SA in April 1967 (an important iron and steel factory); and

5. the teachers strike that mobilized various sectors and unions in February 1968.

However, not all strikes and protests in this period were as successful as those listed above. For example, the baker's strike (September-October 1967) was organized by a union with a tradition of struggle and strong links to the Salvadoran Communist Party (PCS). Unlike the rest of the strikes of the period, this strike did not end well for the workers and it was not able to achieve its demands. In this period, such strikes were the most common strategy of the independent unions. There is no doubt that the unions' use of such tactics was possible because of the strengthening of workers' rights and the rise in union membership. The strike option was also connected to the fact that the unions were mostly formed and based in the cities, around urban working and educational areas. However, some of these strikes expanded across the entire national territory. Certain scholars point out that in addition to how pervasive these strikes were in El Salvador, they were characteristically pacific. ${ }^{29}$ However, as we can see, the most important strikes of the period (as the Acero SA strike in 1967 and the teachers strike in February 1968) included disruptive actions from the workers as well as from the organization of groups in charge of the workers' defense. ${ }^{30}$

It is also important to note that the demands were directed toward the executive branch and the Legislative Assembly. Mostly, they requested an increase in labor protections, or state intervention in a conflict within the private sector. This was a way to put pressure on the government so it would implement reformist policies. They also pushed for more swift recognition of the legality of strikes and broader protections against massive layoffs. This shows that the government was perceived as a legitimate interlocutor. It also shows that workers 
accepted that the State could act on their behalf. ${ }^{31}$ These factors differentiate these strikes from those that took place at the end of the 1970s. In the latter, the increase in state repression changed the relationship between the government and the independent unions. ${ }^{32}$

The 1967 and 1968 strikes aimed to demonstrate the contradictions in the government's actions, which were characterized by the combined use of repression and concessions, as well as by an unclear relationship with the business sector. Strikes managed to show clearly the evolving nature of the relationships between the government and workers and between the government and businesses. As for employers, they created the "Salvadoran Industrial Association" (ASI) in 1967. This shows that even though employers continued to have influence over the executive power, they considered it necessary to constitute a group to defend their interests. ${ }^{33}$ During these strikes, the independent unions reinforced two main characteristics: their autonomy, and their capacity to articulate their influence into different sectors. These two characteristics made the unions extremely dangerous to both the government and the most powerful economic sectors. These attributes characterized the network of organizations capable of sustaining an important critique of the economic order.

The strikes of this period created a context where a new generation of political leaders learned how to use contextually novel political and organizational resources. Those who constituted the first armed organization of El Salvador, Fuerzas Populares de Liberación (Popular Forces of Liberation, or FPL), were among them. Their leader was Salvador Cayetano Carpio, who was also the General Secretary of the PCS between 1964 and 1970. While he was General Secretary he strongly defended the union's struggle and played a leading role in the most important and combative strikes (like the strike that took place in the factory Acero SA). He left the PCS in 1970 to found the FPL. This organization would later become the largest and most important one in Frente Farabundo Martí de Liberación Nacional (Farabundo Marti National Liberation Front or FMLN). ${ }^{34}$

Due to their magnitude, researchers considered the 1967 ad 1968 strikes to be the pinnacle in the Salvadoran union struggle, until 1977. In the mid-1970s, a new protest wave began and overshadowed the legacy of prior movements, surpassing previous outbreaks in terms of size. The analysis of the 1967-1968 strikes was almost abandoned, and instead, many researchers dedicated themselves to studying the movements of the 1970s. The similarities between the two processes were not fully analyzed and they were sometimes underestimated. $^{35}$

The 1967 and 1968 strikes signaled an interruption in the growth of pro-government unions ${ }^{36}$ and an alliance between the independent unions. ${ }^{37}$ Thus, these strikes mobilized an already-established organizational structure and marked the beginning of a new way of protesting. The relationship between different social sectors included in that structure became stronger. These strong relationships would later be a key element in the popular organizations that appeared afterwards, which were known as "mass fronts." The ability to link multiple sectors-an attribute of the unions analyzed in this paper-would be a characteristic of the mass fronts. ${ }^{38}$ Union Leaders who had participated in the 1967 and 1968 strikes were among the militants who founded the mass fronts in the mid-1970s. Later they became more aligned with armed organizations. The presence of these leaders - who supported the armed struggle since the mid-1970s-modified the unions' practices, orienting their goals toward revolution. ${ }^{39}$ It is worth noting that, Salvador Cayetano Carpio, the FUSS leader, was the one who founded the first Salvadoran guerrilla unit, the Popular Forces of Liberation (FPL). Melida Anaya Montes, the leader of the teachers union, was second in command of the FPL until her death.

\section{Political agitation and a new shift in counterinsurgency}

When Sanchez Hernandez assumed presidency-in a climate of social and political agitation-a shift in the counterinsurgency strategy was noted. Economic trends had changed: coffee prices were lowering, cotton production was affected by drought and pestilence, and sugar stores were piling up unsold because of the lack of external market demand. Unemployment was growing progressively and life conditions were deteriorating. ${ }^{40}$ In addition, the MCCA had reached levels of saturation and social unrest was observed. Complex subjects such as the agrarian reform had taken an unusual space in the press and in public opinion. ${ }^{41}$

Within the context of the labor conflicts, Sanchez formed a cabinet of ministers that combined some progressive elements with strong guarantees for all the economic groups. Colonel Joaquín Saldivar, who had served as the Vice Minister of Defense during the previous term, became the leader of the labor and social security area, while General Fidel Torres, a person Sanchez trusted, handled the defense area. Days after he assumed the position, the front page of the main Salvadoran newspaper ran the headline: "[The President] alerts the police against subversion". The article said: 
I encourage you to comply with your duties and to not pay attention to the subversion agents that attempt to confuse the mind. I have heard these subversion agents telling members of the security forces to stop obeying their bosses... This is an invite to break the morale of the security forces; it's a subversion technique to create chaos and take control of the country and democratic institutions ${ }^{42}$.

A few weeks after, an interview with the Minister of the Interior appeared in the same newspaper in an article titled "El Salvador against totalitarianism." There, he analyzed the conflicts that took place within the first semester and had ended with the Acero S.A. general strike. In the article the Minister stated that the conflicts were based on totalitarian doctrines against which they were struggling. He argued that undercover agents led the protest outbreak. ${ }^{43}$ These statements regarding the communists appeared constantly in the most important Salvadoran newspapers and they preceded a set of announcements that would constitute the shift in the counterinsurgency strategy.

Sanchez Hernandez's military training afforded him more of a counterinsurgency perspective than his predecessors. This was evident through the importance given by Sanchez Hernandez to the Central American Defense Council (CONDECA), a military integration organization. Unlike Rivera, who was scarcely inclined to interfere in other countries' internal matters, Sanchez had adopted North American counterinsurgency techniques. He promoted the idea that since communism didn't recognize geographic borders, the fight against it shouldn't recognize them either. He thus supported the regional fight against communism:

The revolutionary wars and the calls to national freedom... are part of a serious warning that can't be dismissed by the Salvadoran Military...the nature of the current conflicts requires that this government supports the Central American armies' unification to act against any aggressor. ${ }^{44}$

Another clear sign of the shift toward counterinsurgency was the empowerment of ORDEN, the organization created during the previous presidency and financed by the United States. Sanchez removed a large number of Rivera's ministers and gave important places to the main members of ORDEN. Colonel Jose Alberto Medrano stood out amongst them, most notably for his repressive actions; he would later assume the central role in the "death squadrons." Medrano also held a strong relationship with the US embassy and was trusted by the president Sánchez Hernández. He was then appointed National Guard Director. It was at this point when ORDEN extended its actions by incorporating the cities and reinforcing their repressive measures.

During this new stage of ORDEN, one of the first events that the organization participated in was the teachers' strike in February 1968. This event demonstrated that the training received at the beginning of the 1960s by the United States was more useful for these types of actions than for regular peasantry control, a function that had previously been fulfilled by ORDEN. A few months after Sanchez Hernandez took office, the teachers strike was particularly challenging due to its magnitude. It managed to mobilize different social sectors. Among them were the urban working sectors and middle class sectors (college and high school students, teachers, and

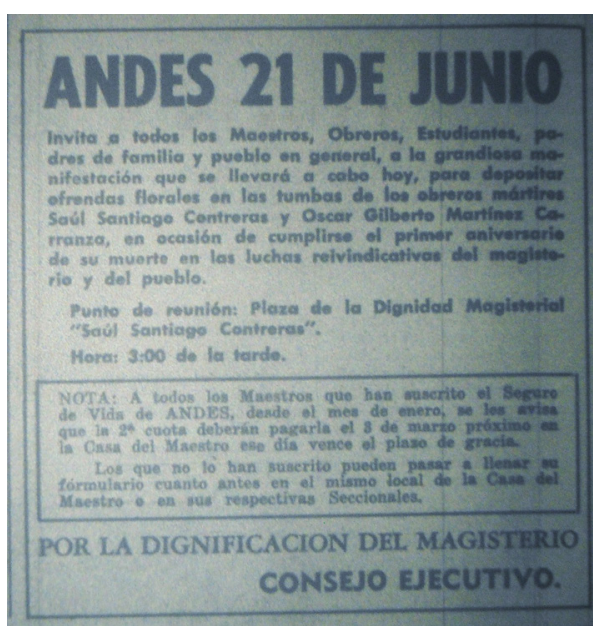

Fig. 4. Teacher's union announcement on year after union leader assassination ${ }^{46}$. Source: La Prensa Gráfica, 1/03/1969. professor associations). There were peasantry associations as well. ${ }^{45}$ This widespread mobilization can be seen in the announcement published a year later (see fig. 4).

Within this context, ORDEN was in charge of the monitoring, kidnapping, and torture of the union leaders that supported teacher protests. It is important to note that the people who died due to the repression against the teachers strike were not teachers but union leaders. They were members of the independent federation of unions, FUSS, who had come to the strike to support teacher demands. This demonstrated that the most feared aspect of teacher mobilizations was their ability to garner support from multiple areas.

Another sign marking the shift in the counterinsurgency (and consequently the change in how worker protests were dealt with) was the creation of the National Security Agency (ANSESAL) in 1967. References to the communist threat had consistently appeared in the national newspapers. On August $30^{\text {th }}$, the headline of La Prensa Gráfica was: "Subversive acts will combat [the Minister of] Defense" while an article titled: 
"Preventative plan by military authority" asserted:

The situation in the country deserves a special discussion considering the new subversive action that constituted a threat to national sovereignty [...]. A national action plan that would reject any insurrection activity has been established. ${ }^{47}$

The article also mentioned that CONDECA approved plans to deter communist infiltration. But the most important article that day was the one that announced the creation of the ANSESAL, the most important organization in the Salvadoran armed forces. This article, titled "Firm actions against subversion", also affirmed that Colonel Medrano would be its director. Another article, titled “Special Organization," detailed:

Colonel Fidel Torres announced officially that there would be a special, new organization that would counter effectively the subversive activities. The National Security Agency is run under Colonel Jose Alberto Medrano, but at the same time it will function with the joint participation of the Defense and Interior Ministry, as well as the special agents belonging to those ministries [...]. It is possible-said Minister Torres- that the OLAS agreements will intensify the preexisting problems and create new ones. The agency will have the power to compile and organize national and international information regarding subversion. ${ }^{48}$

The structure was completed with ANSESAL and ORDEN joining together. As it was pointed out, this structure was created in 1963 in response to the counterinsurgency objectives, but was used in this way only after the 1967-1968 waves of protests.

While ORDEN was in charge of the organization of the rural population and the repression of activists, ANSESAL was a huge military network specialized in the collection, organization, and distribution of information about perceived subversion. ANSESAL was formed by military personnel and constituted an elite force that coordinated the intelligence services at a national level. ${ }^{49}$ Even though in the mid-1970s there were more clear signs of its activity, ANSESAL was created at this time and immediately started to gather information about the insurgency activity in the country. A 1983 report shows that 1 out of every 50 Salvadorans was an ANSESAL informant: "It works as the brain of a security network and reaches every town or neighborhood in the country providing information and organizing the death squad's functions" ${ }^{50}$ The effectiveness was shown by the decrease in strikes since 1968 (see fig. 3). After that, the union fighting would decrease (between 1969 and 1971). ${ }^{51}$ The teachers' strike in 1971 resulted in a temporary reactivation of the mobilization, but it was only in 1977 that mobilization again achieved significant levels.

\section{Conclusion}

This article examines a period of Salvadoran history (1967-1968) that has not been fully analyzed. As noted earlier, most studies of union mobilization dismiss this period and focus on the mobilization that took place in the $1970 \mathrm{~s}^{52}$ Also, this article strives to characterize the role played by the State, marking the different responses to the mobilizations by the government. The presidencies of Rivera (1962-1967) and Sanchez Hernandez (1967-1972), which are frequently considered very similar because of their authoritative character and their contradictory political "openness," are differentiated. As this paper tries to demonstrate, an important shift in counterinsurgency methods can be noted in the Sanchez presidency. That resulted in an empowerment of the counterinsurgency structure and an important change in the way the government dealt with social conflicts.

\section{The article discusses three ideas that can be summarized as follows:}

First, the detailed analysis of the protest outbreak in 1967 and 1968 revealed important characteristics that differentiate it from the 1970s protest wave, marked by the increase in popular agitation, the emergence of the armed organizations, and the deepening of the repression. In this article, these characteristics have been summarized in two ideas: independence of the state and powerful groups (or autonomy), and the ability to articulate different social, political, and geographic sectors. These features allowed the urban unions to sustain a serious critique against the State's economic program and the strategy of co-optation of the official party.

Secondly, the analysis of testimonies, secondary sources, and other documents of that period, allows us to order chronologically the evolution of the counterinsurgency structure. Two different moments were defined: the first phase (between 1963 and 1967) was characterized by the installment of the 
counterinsurgent infrastructure provided by the United States. Even though it was created by the US, it responded to local objectives that were different from the North American counterinsurgent standpoint.

The second phase (between 1967 and 1972) was marked by emphasis on eliminating political agitation. In this sense, this moment began the state's counterinsurgency efforts. This is evident when the importance of the information about a growing subversion that prompted the creation of ANSESAL. It was also evident when they intended to provide the anticommunism struggle using a regional body, the Central American defense organization (CONDECA), instead of instead of a national one. Researchers who have analyzed the political repression during the period prior to insurgency operations in 1972 seem to accept that the presence of counterinsurgent infrastructure was created because the guerilla's threat was imminent. However, documents and academic works written before 1972 note that in this period Salvadoran people mostly believed that there was no possibility for the presence of guerrillas in the country because of the existence of a strong repressive system in such a small territory. ${ }^{53}$

In this respect, this paper contributes insight into the debate surrounding the role played by the United States in the counterinsurgent struggle in Central America. Thus, it is worth repeating that although the United States definitely influenced the characteristics of the counterinsurgent structure in its beginnings, it did not wholly define how this structure functioned once it was implemented. In contrast, the counterinsurgent structure was aimed at resolving obstacles to economic modernization that were defined by a new generation of Salvadoran military. Among those obstacles was the organizational network of middle and working class sectors that had risen since the political opening in 1962. Therefore, the counterinsurgent structure aimed to destroy and reconstruct certain social relationships that threatened the status quo, although they had not yet opted for armed fighting. This is how the government tried to reorganize the social groups to be more favorable to the new economic model. ${ }^{54}$

Finally, this paper attempts to demonstrate the different counterinsurgent measures that were available to neutralize and eventually eliminate social mobilization as it was by the end of the 1960s. Although legal unions supported the social mobilization (we should remember that until 1972 most of the armed groups had not been created yet and the few that were functioning were not important), this mobilization placed the political regime in a place of danger. This happened because, despite the political openness, this regime was based on deep political and economic exclusion. What made the unions dangerous was not their adhesion to communism, but the way they sustained critiques of the economic model. This modality is characterized by its independence (or autonomy) and its ability to group together (or articulate) different social sectors. Although the militants from the Salvadoran Communist Party participated effectively in these organizations, the members of the mobilized sectors were more numerous than the members of this party. It was the breadth and variety of support that enacted a change regarding previous political practices. It also constituted a serious warning to the military governments and an unavoidable record for the mass fronts that would appear later.

\section{End Notes}

1. For interesting nuances and details on this topic, see Ching, E., Lopez Bernal, C. y Tilley, V., Las masas, la matanza y el martinato en El Salvador (San Salvador: UCA Editores, 2007).

2. Turcios, R., Autoritarismo y modernización El Salvador 1950-1960 (San Salvador: Dirección de Publicaciones e Impresos, 2003).

3. Guerra Borges, A., La Integración de América Latina y El Caribe (México: Instituto de Investigaciones Económicas, UNAM, 1997).

4. The interregional commerce was $3.3 \%$ of the exports in the 5 countries in 1950. In 1968, it was over $25 \%$. Central American Gross National Product increased at an annual rate of 6.2\% between 1961 and 1968 (Rouquie, A., Guerras y paz en América Central, México: Fondo de Cultura Económica, 1994). The industrial investments doubled between 1962 and 1967 (Lizano, E. "El proceso de integración económica" en Torres Rivas (coord.) Centroamérica, hoy. México: Editorial Siglo XXI, 1975).

5. Rouquie, A. Guerras y paz.

6. Menjívar, R. Formación y lucha del proletariado salvadoreño (Costa Rica: EDUCA, 1982).

7. Rouquie, A. Guerras y paz.

8. The 1963 electoral reform signaled the change of the traditional electoral system, where the winning party of each department took all the places in the Legislative Assembly. The reform instituted a proportional system that eventually allowed access to non-ruling parties, as shown in the table below. 


\begin{tabular}{|l|l|l|l|l|l|l|l|l|l|l|l|}
\hline Legislative assembly & 1950 & 1952 & 1954 & 1956 & 1958 & 1960 & 1961 & 1964 & 1966 & 1968 & 1970 \\
\hline Official party (PRUD/PCN) & $100 \%$ & $100 \%$ & $100 \%$ & $100 \%$ & $100 \%$ & $100 \%$ & $100 \%$ & $62 \%$ & $60 \%$ & $52 \%$ & $65 \%$ \\
\hline $\begin{array}{l}\text { Christian democracy } \\
\text { (PDC) (most important } \\
\text { opposition party) }\end{array}$ & & & & & & & & $27 \%$ & $29 \%$ & $37 \%$ & $31 \%$ \\
\hline $\begin{array}{l}\text { Other parties (PAR, PPS, } \\
\text { others) }\end{array}$ & & & & & & & & $12 \%$ & $12 \%$ & $12 \%$ & $4 \%$ \\
\hline
\end{tabular}

9. Baloyra, E., El Salvador en transición (El Salvador: UCA Editores, 1984).

10. Between 1964 and 1968 the non-ruling parties' places were more numerous than the pro-government parties. (Rojas Bolaños, "La política", en Perez Brignoli, H., Historia General de Centroamérica. De la posguerra a la crisis (1945-1979) [Tomo V] (Madrid: FLACSO, 2003).

11. According to Cayetano Carpio, who was a referent on labor confederations and also the General Secretary of the Communist Party (PCS) between 1964 to 1970, "The management sector...took the opportunity that the Labor Code from 1963 gave and inserted regulations that made impossible to legally make use of the constitutional right to strike in El Salvador; no strike could be legal according to the Code". Carpio, S., La huelga general obrera de abril (San Salvador: Editorial Farabundo Martí, 1980).

12. The Cuban situation had the greatest impact at that moment; particularly the declaration provided by Fidel Castro in December 1961 about the socialist orientation of the revolution.

13. Dunkerley, The Long War: Dictatorship and Revolution in El Salvador (Londres: Junction Books, 1983).

14. Years later (1966) Robert McNamara explained the reasons for this change: the difficulties in the external relationships were caused by an open intervention along with the local forces' knowledge about geographic and psychological aspects. Also, the training costs were reduced if we compare a Central American soldier with a North American one. According to Dunkerley's calculation in 1983, a Salvadoran's training cost 10 times less than that a North American's.

15. For an extended analysis of the initial phase of the National Guard and other repressive organizations in the beginning of the 20th century, see Alvarenga, P., Cultura y ética de la violencia: El Salvador, 1880-1932 (San Salvador: Dirección de Publicaciones e Impresos, 2006).

16. Gordon Rapoport, S., Crisis política y guerra en El Salvador (México: Editorial Siglo XXI, 1989).

17. Chávez Velasco, W., Lo que no conté sobre los presidentes militares (San Salvador: Índole Editores, 2006), p.121.

18. Gordon Rapoport, S., Crisis política y guerra.

19. Dunkerley, The Long War.

20. Vilas, C., Mercado, Estados y revoluciones. Centroamérica 1950-1990 (México: Universidad Nacional Autónoma de México, 1994).

21. For a testimony of the relationship between ORDEN and peasantry population, see López Vigil M., Don Lito de El Salvador: habla un campesino (San Salvador: UCA Editores, 1987).

22. Valle, V., Siembra de vientos. El Salvador 1960-1969 (San Salvador: Centro de Investigación y Acción Social: 1993), p.18.

23. The PAR (Renewal Action Party) was founded in 1948 by right-wing leaders and occupied in 1965 by left-wing leaders that included communist militants. It was the first one to propose and discuss the agricultural reform, ending the taboo on this matter that had been in place since the massacre of 1932. PAR was aware that they had no chances to win but they use the 1967 campaign as an opportunity to promote their proposals.

24. Menjívar, Formación y lucha.

25. Gordon Rapoport, Crisis política y guerra.

26. The cover reads: "Rivera looks for a solution to the strike." The picture shows President Rivera having a caring conversation with the union representatives, 5 days before one of these sectors organized a progressive strike. Newspaper: La Prensa Gráfica, 21/04/1967.

27. The military that supported this authoritarian and developmental program believed that the formation of a broad social base along with the companies' support would allow them to undermine the power of the oligarchy. They later wanted to maintain El Salvador in the agro-export stage. When the autonomous unions started to compete successfully for the social base the government plans and measures became more difficult to implement.

28. Almeida, P., Waves of protest: popular struggle in El Salvador, 1925-2005 (Minneapolis: University of Minnesota Press, 2008).

29. The registry shows 971 events occurred between 1967 and 1972 where $30 \%$ were strikes, $21 \%$ were requests, $17 \%$ were protests and $3 \%$ were the occupations of buildings. (Almeida, P, Waves of protest). Also see Gordon, Crisis política y guerra.

30. For example: "Comisión de Garroteros" (big stick commission) described by Carpio, La huelga general.

31. Almeida, Waves of protest.

32. Pirker, K., "Radicalización política y movilización social en El Salvador: los frentes de masas" en Molinari, Lucrecia (ed.), 
Observatorio Latinoamericano, Dossier El Salvador [on line] vol. 9., noviembre de 2012. [Access 15/11/12] http://iealc. sociales.uba.ar/publicaciones/observatorio-latinoamericano/.

33. See description of ASI's actions in Carpio's chronicle (Carpio, S., La huelga general).

34. In October 10th, 1980 the 5 groups, PCS, FPL, ERP (Popular Revolutionary Army), RN (National Resistance) and PRTC (Central American Revolutionary Party of Workers) combined to create FMLN.

35. Some of the most important studies of the 1970s movilizations published at that time were Álvarez Solís, A., M. López Vigi y J. Morales, El Salvador: la larga marcha del pueblo (1932-1982) (Madrid: Editorial Revolución, 1982), Lungo, M., La lucha de masas en El Salvador (San Salvador: UCA Editores, 1987), Menéndez Rodríguez M., El Salvador: Pueblo contra oligarquía (México: Universidad Autónoma de Sinaloa, 1981) y Menjívar, Formación y lucha.

36. The supremacy of the pro-government unions was reversed in 1967. By 1971 this group had only $42 \%$ of the unions, and this was further reduced to $19 \%$ in 1976. Dunkerley, The Long War.

37. Comisión Organizadora de Brigadas Obreras, El movimiento obrero en El Salvador, 1920-1977 [doccument], s.l., agosto de 1977)

38. The mass fronts developed a strong connection to the guerrillas by the end of the 1970s. They became very important to the survival of the revolutionary organizations. For an analysis of the Mass fronts, see Pirker, K. La redefinición de lo posible: Militancia política y movilización social en El Salvador (1970-2004). Unpublished doctoral thesis, Universidad Nacional Autónoma de México, Colegio de Estudios Latinoamericanos, México, 2008.

39. Pirker, Radicalización política.

40. Webre, S., José Napoleón Duarte y el Partido Demócrata Cristiano en la política salvadoreña, 1960-1972 (San Salvador: UCA, 1985).

41. Ramírez Fuentes, J., El discurso anticomunista de las derechas y el Estado como antecedente de la Guerra Civil en El Salvador (1967-1972). Unpublished thesis, Universidad de El Salvador, Facultad de Ciencias y Humanidades, El Salvador, 2008.

42. Newspaper La Prensa Gráfica, 7/7/1967

43. Newspaper La Prensa Gráfica, 22/8/1967

44. Quoted by Monteforte Toledo, M., Centro América: subdesarrollo y dependencia (México: Instituto de Investigaciones Sociales, Universidad Nacional Autónoma de México, 1972), p.192.

45. Gordon Rapoport, Crisis política y guerra.

46. "ANDES June, 21st is inviting all teachers, workers, students, parents, and the public to a protest that will be performed today to lay flowers on the workers Saul Santiago Contreras and Oscar Gilberto Martinez Carranza's graves considering it's been one year since their deaths fighting for the people." Location: Plaza de la Dignidad Magisterial 'Saúl Santiago Contreras'...”For Teachers dignity." La Prensa Gráfica, 1/03/1969.

47. Newspaper La Prensa Gráfica, “Preventive plan by Military Authority”, 30/08/1967.

48. Ibid.

49. Siegel, D. y Hackel, J., "El Salvador: la nueva visita de la contrainsurgencia", en Klare, M. y Kornbluh, P. (coords.) Contrainsurgencia, proinsurgencia y antiterrorismo (Buenos Aires: Editorial Grijalbo, 1990).

50. Torres Rivas, E., “Centroamérica: Guerra, transición y democracia”. Revista Iztapalapa. vol. 2, núm. 20, 1990, p.58.

51. See the description of the union scene provided during the falling stage by Carpio, S., Las corrientes sindicales en El Salvador. Revista La Universidad, Revista bimestral de la Universidad de El Salvador, núm. 6, 1969.

52. Álvarez Solís, López Vigil y Morales, El Salvador: la larga marcha; Lungo, La lucha de masas; Menéndez Rodríguez, E Salvador: Pueblo contra oligarquía; y Menjívar, Formación y lucha.

53. A very clear example is White, A., El Salvador, (San Salvador: UCA Editores, 2001) and Anaya Montes, M., La segunda gran batalla de ANDES 21 de Junio (San Salvador: Editorial Universitaria de El Salvador, 1972).

54. This type of goals is analyzed by Feierstein, D., El genocidio como práctica social: entre el nazismo y la experiencia argentina (Buenos Aires: Fondo de Cultura Económica, 2007). See especially his concept of 'reorganizational genocide'. 